\title{
Survivable hypothermia or torpor in a wild-living rat: rare insights broaden our understanding of endothermic physiology
}

\author{
Julia Nowack ${ }^{1,2} \oplus$ Christopher Turbill ${ }^{1}$
}

Received: 23 March 2021 / Revised: 8 September 2021 / Accepted: 3 October 2021 / Published online: 19 October 2021

(c) The Author(s) 2021

\begin{abstract}
Maintaining a high and stable body temperature as observed in endothermic mammals and birds is energetically costly. Thus, it is not surprising that we discover more and more heterothermic species that can reduce their energetic needs during energetic bottlenecks through the use of torpor. However, not all heterothermic animals use torpor on a regular basis. Torpor may also be important to an individual's probability of survival, and hence fitness, when used infrequently. We here report the observation of a single, $\sim 5.5 \mathrm{~h}$ long hypothermic bout with a decrease in body temperature by $12{ }^{\circ} \mathrm{C}$ in the native Australian bush rat (Rattus fuscipes). Our data suggest that bush rats are able to rewarm from a body temperature of $24^{\circ} \mathrm{C}$, albeit with a rewarming rate lower than that expected on the basis of their body mass. Heterothermy, i.e. the ability to withstand and overcome periods of reduced body temperature, is assumed to be an evolutionarily ancestral (plesiomorphic) trait. We thus argue that such rare hypothermic events in species that otherwise appear to be strictly homeothermic could be heterothermic rudiments, i.e. a less derived form of torpor with limited capacity for rewarming. Importantly, observations of rare and extreme thermoregulatory responses by wild animals are more likely to be discovered with long-term data sets and may not only provide valuable insight about the physiological capability of a population, but can also help us to understand the constraints and evolutionary pathways of different phenologies.
\end{abstract}

Keywords Heterothermy $\cdot$ Homeothermy $\cdot$ Native Australian rodent $\cdot$ Bush rat $\cdot$ Rewarming $\cdot$ Cooling

\section{Introduction}

As endotherms, mammals and birds are characterised by metabolically defending a near-constant body temperature $\left(\mathrm{T}_{\mathrm{b}}\right)$ by regulatory feedback mechanisms in the hypothalamus (Zhao et al. 2017). The maintenance of $T_{b}$ within a narrow range of optimal temperatures has several advantages, such as sustained aerobic activity, independence from environmental conditions and optimisation of enzyme activity, but endothermy comes with a high energetic cost

Communicated by P. Withers.

Julia Nowack

J.Nowack@ljmu.ac.uk

1 Hawkesbury Institute for the Environment and School of Science, Western Sydney University, Richmond, NSW, Australia

2 Present Address: School of Biological and Environmental Sciences, Liverpool John Moores University, Byrom Street, Liverpool L3 3AF, UK relative to ectothermic species (Nagy 2005). This energetic cost is particularly high for smaller species, and increases with decreasing ambient temperature $\left(\mathrm{T}_{\mathrm{a}}\right)$ below the animal's thermal neutral zone (Bennett and Ruben 1979). Thus, given that food is often not continuously available, it is not surprising that some mammals and birds can lower their metabolically defended $T_{b}$ in a controlled state known as torpor (Geiser 2004). During torpor, the metabolic rate of an animal is reduced in correspondence with the reduction in $T_{b}$ and the animal is able to rapidly rewarm from its low $T_{b}$ by endogenously fuelled heat production. This process is fundamentally different from unregulated hypothermia, during which $T_{b}$ is equally reduced, but metabolic rate remains high as the animal is attempting to generate as much metabolic heat as possible to defend its $T_{b}$ against a further decline. Torpor by so-called heterothermic endotherms, therefore, can provide a pronounced reduction of the animal's daily energy expenditure (Geiser 2004). The resulting energy saving provides these species with greater flexibility in managing the combined risks of starvation and predation under variable environmental conditions (Turbill 
et al. 2011, 2019; Turbill and Stojanovski 2018). To date, we know more than 171 species of mammals and 43 bird species that are capable of using torpor (Ruf and Geiser 2015). Numbers of heterothermic species are steadily increasing, partly because ongoing technological advances in biologging equipment (Chmura et al. 2018) allow $T_{b}$ to be recorded in a greater range of wild-living animals, which are more likely to exhibit torpor compared to captive animals (Geiser et al. 2000). Notable recent additions of species using torpor in the wild include a primate - the pygmy slow loris (Ruf et al. 2015), a passerine - the superb fairy-wren (Romano et al. 2019), and the discovery of multiday torpor in response to a flood event in golden spiny mice, a species that had been described previously as undergoing only short bouts of torpor for a few hours (Barak et al. 2018). While it is relatively easy to discover and describe torpor use in species that are using torpor on a regular basis, torpor could also be important to an individual's probability of survival, and hence fitness, when used infrequently, such as in response to extreme weather events (Nowack et al. 2015), and these rare torpor bouts require long-term data sets of wild-living animals (see Nowack et al. (2020) for a recent list of species that are known to use torpor only rarely).

Australia's native rodent species are one group of mammals that might be expected to use torpor, but for which we have very little data on $\mathrm{T}_{\mathrm{b}}$, especially in wild-living animals. At least $40 \%$ of Australia's native mammals are known to use torpor, yet although native rodents make up approximately $25 \%$ of Australian mammal species (Geiser and Körtner 2010), only one native species, the ash-grey mouse Pseudomys albocinereus has been shown to be capable of employing regulated torpor in the laboratory at $\mathrm{T}_{\mathrm{a}}$ of 20 and $25{ }^{\circ} \mathrm{C}$ (Barker et al. 2012). Hypothermic bouts have also been recorded in the sandy mouse, Pseudomys hermannsburgensis (Tomlinson et al. 2007), but heterothermy in $P$. hermannsburgensis is assumed to represent hypothermia (Tomlinson et al. 2007), i.e. a non-controlled, non-reversible drop in $\mathrm{T}_{\mathrm{b}}$. In addition, the house mouse, Mus musculus, an introduced species that lives in natural environments in Australia, shows daily torpor in the wild (Morton and Lee 1978) and in captivity in response to increased energy expenditure (Schubert et al. 2010) or increased perceived predation risk (Turbill and Stojanovski 2018), and a recent paper has revealed that juvenile mice use torpor during their development (Renninger et al. 2020). All other studies on thermoregulation of native Australian rodent species, such as the bush rat (Rattus fuscipes), so far suggest they are strictly homeothermic species that regulate their $T_{b}$ within a narrow range (e.g. Glanville and Seebacher 2010). One reason for this might be a lack of field-based data. Bush rats are a particularly well-studied species, but all studies on bush rats have either been laboratory studies (Seebacher and Glanville 2010; Glanville et al. 2012) or short field studies lasting $<3$ weeks (Glanville and Seebacher 2010), while longer term field data might be required to document the physiological breath of a species (Geiser et al. 2000, 2007). For example, studies comparing torpor use in sugar gliders under laboratory and field conditions have revealed differences in activity pattern as well as a difference in $T_{b}$ regulation with a lower normothermic $\mathrm{T}_{\mathrm{b}}$ and more frequent and deeper torpor bouts in the wild (Geiser et al. 2007).

We present long-term $T_{b}$ data from free-ranging individuals of the native Australian bush rat (Rattus fuscipes), a species endemic to Australia, recorded during the austral autumn and early winter seasons. These data were collected during a broader study that aimed to test for within-individual correlations and among-individual differences in behavioural and physiological traits in wild rats. Among 1047 individual-days of $T_{b}$, we recorded a single observation of a $12{ }^{\circ} \mathrm{C}$ decrease in $\mathrm{T}_{\mathrm{b}}$ over $5.5 \mathrm{~h}$ during the resting phase for one individual. This paper focusses on this unique observation and discusses its implications for our understanding of endothermic thermoregulation.

\section{Methods}

\section{Animals}

We captured a total number of 30 bush rats in walk-in live traps (Elliott traps, type A) in the Blue Mountains, approximately $60 \mathrm{~km}$ WNW of Sydney, Australia (S 33.60994, E 150.63809) between March and May 2016. Traps were baited with rolled oats and peanut butter in the afternoon and checked in the early morning. After capture, rats were transported to Hawkesbury Campus of Western Sydney University, where they were fitted with a subcutaneous microchip for individual identification (PIT tag; Trovan ID100 Midichip) and surgically implanted with a temperature-sensitive data logger before being released (ibutton; DS1922L-F5\#, resolution: $0.0625{ }^{\circ} \mathrm{C}$, accuracy improved to $0.1{ }^{\circ} \mathrm{C}$ by calibration, logging interval: every $30 \mathrm{~min}$; Maxim Integrated Products, Inc., Sunnyvale, California, USA; surgery details below). Temperature loggers were waxed in Elvax and calibrated before use in a water bath to the nearest of $0.1{ }^{\circ} \mathrm{C}$ (high precision NIST traceable digital thermometer; Control Company, Texas) from 5 to $40{ }^{\circ} \mathrm{C}$. Loggers weighed $<3 \mathrm{~g}$ after waxing, which is $<5 \%$ of the body mass of adult bush rats (rats weighed between 59 and $137 \mathrm{~g}$ ). After recovery from surgery (details below), rats were released at the exact capture location. We re-captured 14 of 30 implanted rats in June and July 2016 (recapture rate: 47\%) and recorded a total of 1047 individual-days of $\mathrm{T}_{\mathrm{b}}$ data between March and June 2016 (42-87 days per animal (Table 1), $N=14$ animals ( $9 \mathrm{~m}$, $5 \mathrm{f}$ ), average body mass: $92 \pm 21 \mathrm{~g}$ ). 
Table 1 Overview of data recording

\begin{tabular}{llll}
\hline Animal & $\begin{array}{l}\text { Release/recording } \\
\text { start date }\end{array}$ & $\begin{array}{l}\text { Recapture/recording } \\
\text { end date }\end{array}$ & $\begin{array}{l}\text { Number } \\
\text { of days }\end{array}$ \\
\hline 1 & 14 March & 02 June & 80 \\
2 & 14 March & 01 June & 79 \\
3 & 14 March & 01 June & 79 \\
4 & 20 March & 14 June & 87 \\
5 & 27 March & 12 June & 77 \\
6 & 27 March & 12 June & 77 \\
7 & 27 March & 12 June & 77 \\
8 & 27 March & 12 June & 77 \\
9 & 04 April & 19 June & 76 \\
10 & 04 April & 19 June & 76 \\
11 & 12 April & 28 June & 77 \\
12 & 12 April & 28 June & 77 \\
13 & 22 April & 29 June & 66 \\
14 & 17 May & 29 June & 42 \\
\hline
\end{tabular}

The table indicates the recording period as well as the total number of recording days per animal

\section{Surgery details}

Sterile transmitters were implanted intraperitoneally under general oxygen-isoflurane anaesthesia through a small $(1-2 \mathrm{~cm})$ abdominal incision. Pain relief was achieved by a single subcutaneous injection of a non-steroidal antiinflammatory (carprofen). The skin and muscle fascia incisions were sutured separately using vicryl absorbable suture (Vicral Ethicon, Johnson \& Johnson, Somerville, New Jersey, USA), and a topical anaesthetic (Xylocaine) and Leuko spray bandage plastic skin (BSN Medical, Clayton, Victoria, Australia) were applied. Post-surgery, animals were kept individually at $20 \pm 2{ }^{\circ} \mathrm{C}$ and monitored closely. Animals were allowed to recover for up to 7 days before being released. All released animals appeared in good body condition and surgery wounds had healed well. Explantation of loggers from re-captured animals followed the same protocol as specified above.

\section{Ambient conditions}

Ambient temperature was recorded within the trapping area via temperature loggers placed in the shade at a height of $1.2 \mathrm{~m}$ from the ground (ibutton, DS1922L-F5\#, resolution: $0.0625{ }^{\circ} \mathrm{C}$; Maxim Integrated Products, Inc., Sunnyvale, California, USA). Rainfall and solar radiation data for the whole study duration as well as minimum and maximum $\mathrm{T}_{\mathrm{a}}$ for 6 days for which we were lacking ibutton data (14.03 to 19.03.2016) was sourced from the nearby weather station ( $\sim 13 \mathrm{~km}$ away, Richmond RAAF, Australian Government Bureau of Meteorology; Pearson correlation coefficient was calculated to test the correlation between ibutton and weather station data and showed a high correlation for minimum $(R=0.92)$ as well as maximum $\left.\mathrm{T}_{\mathrm{a}}(R=0.90)\right)$.

\section{Data analysis}

Data analysis was conducted in $\mathrm{R}$ version 3.6.2 ( $\mathrm{R}$ Development Core Team 2019). Data are presented as mean \pm 1 standard deviation. $N$ denotes the number of individuals, $n$ the cumulative days of data recorded. $\mathrm{T}_{\mathrm{b}}$ data were analysed by assigning each $\mathrm{T}_{\mathrm{b}}$ datum to either nighttime (activephase) or daytime (rest-phase) following Levesque et al. (2018). Plotting the frequency distribution of all data, we found a bi-modal distribution of $T_{b}$ and calculated modal $\mathrm{T}_{\mathrm{b}}$ of daytime (resting) and modal $\mathrm{T}_{\mathrm{b}}$ of nighttime (activity). Sunset and sunrise data for the analysis and plots were calculated using the R package 'maptools' (Bivand and LewinKoh 2019), which is using the following website: https:// www.esrl.noaa.gov/gmd/grad/solcalc/sunrise.html. Linear mixed effects models ("Ime" in package 'nlme', Pinheiro et al. (2021)) followed by type 1 ANOVA were used to test the influence of minimum or maximum $\mathrm{T}_{\mathrm{a}}$ on minimum, maximum $\mathrm{T}_{\mathrm{b}}$ and the daily amplitude. All models accounted for repeated measures by including animal ID as random effect on the intercept. Normal distribution of residuals was checked visually and using Shapiro-Wilk tests and nonnormally distributed data were boxcox transformed prior to carrying out the analysis. Pearson correlation coefficient was calculated to test the correlation between daily minimum and maximum $\mathrm{T}_{\mathrm{a}}$. Rayleigh tests were used to determine whether circular data (timing of $\mathrm{T}_{\mathrm{b}}$ above/below $38^{\circ} \mathrm{C}$ ) differed significantly from random distribution ("rayleigh.test" in package 'circular', Agostinelli and Lund (2017)).

\section{Results}

\section{Ambient conditions}

Mean daily $\mathrm{T}_{\mathrm{a}}$ during the study period ranged from 5.8 to $22.6{ }^{\circ} \mathrm{C}$, with an absolute nightly minimum of $0.6^{\circ} \mathrm{C}$ at the end of May and an absolute daytime maximum of $34.6^{\circ} \mathrm{C}$ at the end of March. Monthly average mean and maximum $\mathrm{T}_{\mathrm{a}}$ decreased progressively from March to June, whereas average monthly minimum $T_{a}$ was lowest in May (Table 1). Daily minimum and maximum $\mathrm{T}_{\mathrm{a}}$ were strongly correlated $(R=0.99)$. Daylength decreased from just more than $12 \mathrm{~h}$ (12 h $6 \mathrm{~min}$ ) in March to less than $10 \mathrm{~h}$ ( $9 \mathrm{~h} 54 \mathrm{~min}$ ) in June. Daily amplitude in $\mathrm{T}_{\mathrm{a}}$ ranged from 2 to $19^{\circ} \mathrm{C}$. Rainfall was low during March to May (4.2-12.8 mm per month) but increased in June (189.2 mm per month). Daily solar radiation was highest in March (monthly average: $16.3 \mathrm{MJ} \mathrm{m}^{-2}$ ) and decreased continuously until June (monthly average 
$8.8 \mathrm{MJ} \mathrm{m}^{-2}$ ), with an absolute minimum during the study of $2.2 \mathrm{MJ} \mathrm{m}^{-2}$ in early June.

\section{Variation in body temperature}

Daily mean $\mathrm{T}_{\mathrm{b}}$ of bush rats ranged between 37.4 and $37.6^{\circ} \mathrm{C}$ during the study period $(N=14)$. $\mathrm{T}_{\mathrm{b}}$ showed a clear bi-modal distribution with a daytime modal $\mathrm{T}_{\mathrm{b}}$ of $36.5^{\circ} \mathrm{C}$ and a nighttime modal $\mathrm{T}_{\mathrm{b}}$ of $38.3^{\circ} \mathrm{C}$ (Fig. 1A,B). Average daily maximum $\mathrm{T}_{\mathrm{b}}$ was relatively stable and not influenced by minimum $\left(F_{1,1031}=3.4, p=0.0636\right)$ or maximum $\mathrm{T}_{\mathrm{a}}\left(F_{1,1031}=1.6\right.$, $p=0.2032)$. Daily minimum $\mathrm{T}_{\mathrm{b}}$ decreased from autumn to winter (Table 2) and was significantly influenced by minimum $\mathrm{T}_{\mathrm{a}}\left(F_{1,1031}=143.03, p<0.001\right)$, i.e. rats had a lower $\mathrm{T}_{\mathrm{b}}$ during colder days. Daily amplitude between minimum and maximum $\mathrm{T}_{\mathrm{b}}$ ranged from 1.4 to $5.4^{\circ} \mathrm{C}$, with the exception of one occasion when an animal decreased its $\mathrm{T}_{\mathrm{b}}$ by $>12{ }^{\circ} \mathrm{C}$ (see below), and daily $\mathrm{T}_{\mathrm{b}}$ amplitude was significantly positively influenced by minimum $\mathrm{T}_{\mathrm{a}}\left(F_{1,1031}=126.5, p<0.001\right.$, Table 2$)$, as well as by daily amplitude in $\mathrm{T}_{\mathrm{a}}\left(F_{1,1031}=20.5\right.$, $p<0.001)$.

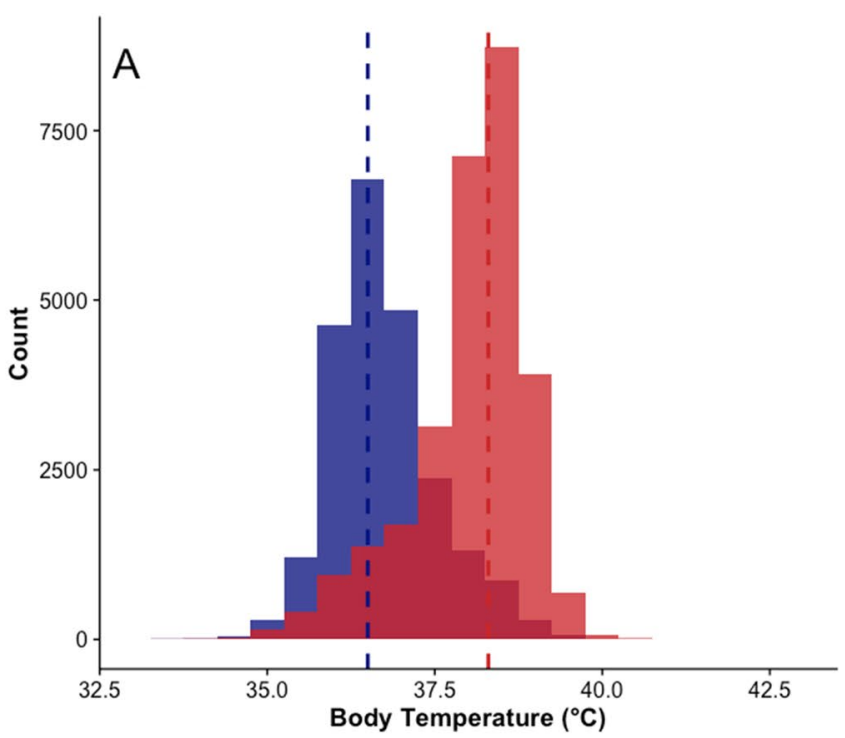

Fig. 1 Body temperature pattern of bush rats $\mathbf{A}$ Body temperature distribution of bush rats $(N=14, n=1047)$ over the total study duration (March-June). Blue bars represent daytime body temperature values, red bars nighttime values. B Exemplary body temperature trace

\section{Hypothermic bout}

One subadult female (76 $\mathrm{g}$ at first capture) showed a large decrease in $\mathrm{T}_{\mathrm{b}}$ beginning on the 7 th of May (autumn; Fig. 2A, B), reaching a minimum daily $\mathrm{T}_{\mathrm{b}}$ of $23.8^{\circ} \mathrm{C}$ and $\mathrm{T}_{\mathrm{b}}$ remaining $<30{ }^{\circ} \mathrm{C}$ for at least $5.5 \mathrm{~h}(0720 \mathrm{~h}$ to $1250 \mathrm{~h}$; $30 \mathrm{~min}$ recording interval). On the day of the hypothermic bout, $\mathrm{T}_{\mathrm{b}}$ of this individual peaked to above $39{ }^{\circ} \mathrm{C}$ at about $1.5 \mathrm{~h}$ before sunset and remained high for only $1.5 \mathrm{~h}$ before $\mathrm{T}_{\mathrm{b}}$ was reduced to resting level (mean: $35.9{ }^{\circ} \mathrm{C}$ ) and kept low until the early morning. On all other days in May, $\mathrm{T}_{\mathrm{b}}$ only rose $>38^{\circ} \mathrm{C}$ after sunset (mean $1753 \mathrm{~h}$, timing different from random distribution: Rayleigh test, $r=0.9529, p<0.001$ ) and dropped back to $<38{ }^{\circ} \mathrm{C}$ only at a time just before sunrise (mean $0455 \mathrm{~h}$, Rayleigh test: $r=0.908, p<0.001$ ). On the day of the hypothermic bout, $\mathrm{T}_{\mathrm{b}}$ started to continuously decrease further at about $2.5 \mathrm{~h}$ before sunrise and reached a minimum at around $0850 \mathrm{~h}$. Ambient temperature at this time was $15.2^{\circ} \mathrm{C}\left(\mathrm{T}_{\mathrm{b}}-\mathrm{T}_{\mathrm{a}}\right.$ differential: $8.6^{\circ} \mathrm{C}$, Fig. 2$)$.

Cooling rate of the animal during entry into the hypothermic bout varied from 0.5 to $3.9^{\circ} \mathrm{C} \mathrm{h}^{-1}$ measured over 10 min (i.e. $<0.01$ to $0.07{ }^{\circ} \mathrm{C} \min ^{-1}$, Fig. 2). Maximum

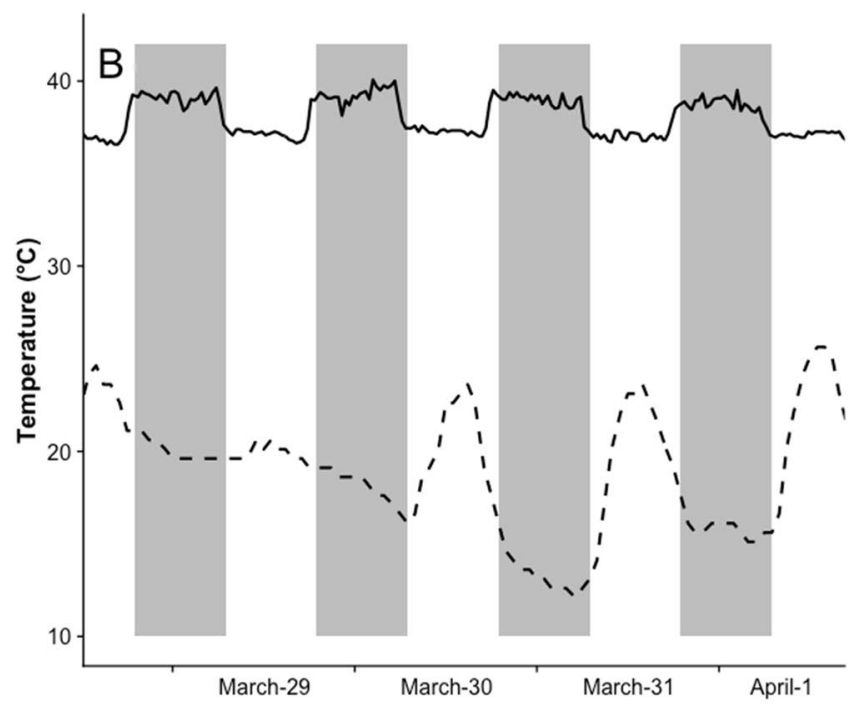

over 4 days in March/April of a female bush rat. Solid line: body temperature, dashed line: ambient temperature, shaded areas illustrate nighttime.
Table 2 Monthly average body temperature and ambient temperature values, including number of sampling days $(n)$

\begin{tabular}{lccccccc}
\hline Month & $n$ & $\mathrm{~T}_{\mathrm{b}} \min \left({ }^{\circ} \mathrm{C}\right)$ & $\mathrm{T}_{\mathrm{b}} \max \left({ }^{\circ} \mathrm{C}\right)$ & $\mathrm{T}_{\mathrm{b}} \operatorname{mean}\left({ }^{\circ} \mathrm{C}\right)$ & $\mathrm{T}_{\mathrm{b}}$ amplitude $\left({ }^{\circ} \mathrm{C}\right)$ & $\mathrm{T}_{\mathrm{a}} \min \left({ }^{\circ} \mathrm{C}\right)$ & $\mathrm{T}_{\mathrm{a}} \max \left({ }^{\circ} \mathrm{C}\right)$ \\
\hline March & 18 & $36.4 \pm 0.5$ & $39.1 \pm 0.3$ & $37.6 \pm 0.4$ & $2.8 \pm 0.3$ & $16.4 \pm 3.0$ & $27.6 \pm 4.4$ \\
April & 30 & $36.1 \pm 0.3$ & $39.1 \pm 0.2$ & $37.5 \pm 0.2$ & $3.0 \pm 0.4$ & $12.9 \pm 2.0$ & $21.9 \pm 2.7$ \\
May & 31 & $35.9 \pm 0.4$ & $39.1 \pm 0.2$ & $37.4 \pm 0.3$ & $3.2 \pm 0.5$ & $7.3 \pm 2.8$ & $19.2 \pm 2.7$ \\
June & 28 & $36.0 \pm 0.5$ & $39.1 \pm 0.3$ & $37.5 \pm 0.3$ & $3.1 \pm 0.5$ & $7.6 \pm 3.1$ & $15.0 \pm 1.8$ \\
\hline
\end{tabular}




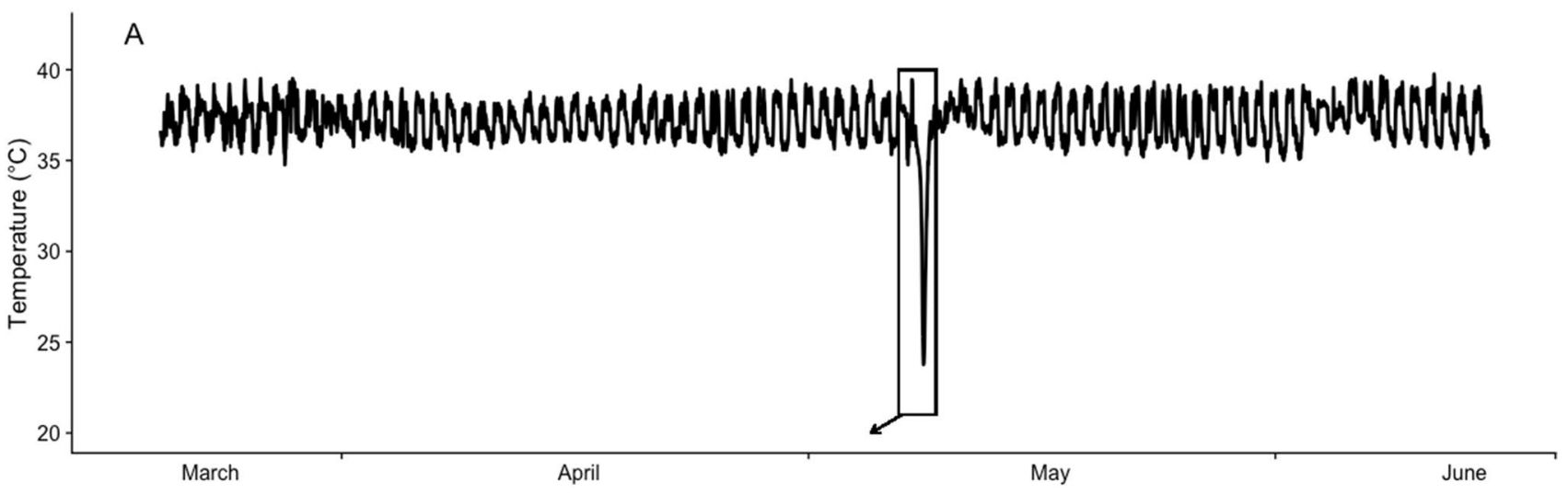

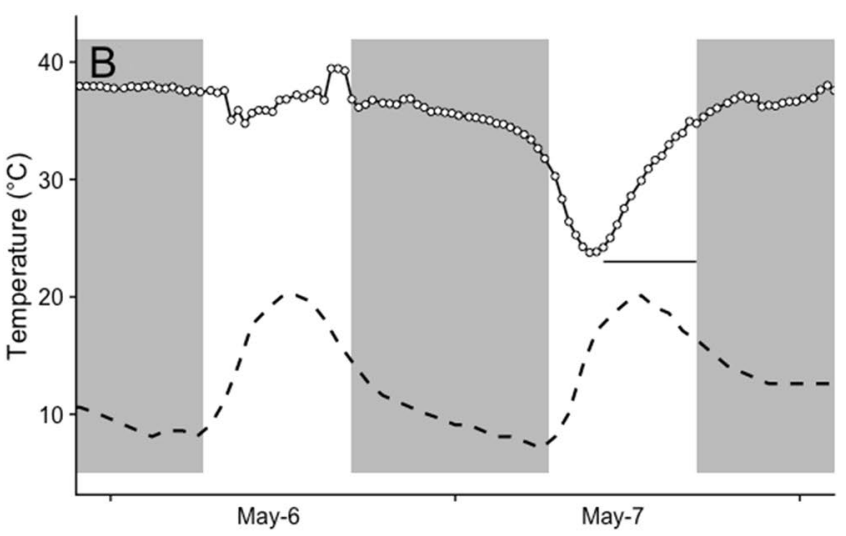

Fig. 2 Hypothermic bout of female bush rat (Rattus fuscipes) A Body temperature recording from March to June $\mathbf{B}$ Body temperature trace of the days around the hypothermic bout; solid line: body temperature, dashed line: ambient temperature, grey: night phase, horizontal line indicates the time period of warming body temperatures depicted

cooling rate was reached at a $\mathrm{T}_{\mathrm{b}}$ of $30^{\circ} \mathrm{C}$ and cooling rate slowed down again before reaching minimum $\mathrm{T}_{\mathrm{b}}$. Minimum $\mathrm{T}_{\mathrm{b}}$ of around $24{ }^{\circ} \mathrm{C}\left(23.8\right.$ to $\left.24.3{ }^{\circ} \mathrm{C}\right)$ was maintained for about $1.5 \mathrm{~h}$. Body temperature of the animal started to increase again in the early morning, reaching $>30{ }^{\circ} \mathrm{C}$ at around midday and back to a normal resting level $\mathrm{T}_{\mathrm{b}}$ of $\sim 35{ }^{\circ} \mathrm{C}$ in the afternoon (after $\sim 6 \mathrm{~h}$; Fig. $2 \mathrm{~A}, \mathrm{~B}$ ). Rewarming rate of the bush rat was fastest at a $\mathrm{T}_{b}$ below $30{ }^{\circ} \mathrm{C}$ and slowed down thereafter (Fig. 2C). Maximum rewarming rate of $2.75{ }^{\circ} \mathrm{C} \mathrm{h}^{-1}$ (i.e. $0.05{ }^{\circ} \mathrm{C} \mathrm{min}{ }^{-1}$; Fig. 3) was reached at around $1200 \mathrm{~h}$ and was faster than warming of the environment (Fig. 2C). Ambient temperature reached a minimum of $8.1{ }^{\circ} \mathrm{C}$ at $0600 \mathrm{~h}$ and warmed thereafter, with a maximum warming rate occurring between 0800 and $0900 \mathrm{~h}$. After $1000 \mathrm{~h}, \mathrm{~T}_{\mathrm{a}}$ rose between 1.5 and $2.0{ }^{\circ} \mathrm{C} \mathrm{h}^{-1}\left(\sim 0.03{ }^{\circ} \mathrm{C} \mathrm{min}^{-1}\right)$ until $12 \mathrm{pm}$, then by $0.5^{\circ} \mathrm{C} \mathrm{h}^{-1}\left(<0.01{ }^{\circ} \mathrm{C} \mathrm{min}^{-1}\right)$ until daytime maximum temperature of $21.7^{\circ} \mathrm{C}$ was reached at $1 \mathrm{pm}$ and $\mathrm{T}_{\mathrm{a}}$ started to decrease again (Fig. 2C). The day of the hypothermic bout had no rainfall and a daily solar radiation of $13.7 \mathrm{MJ} \mathrm{m}^{-2}$.

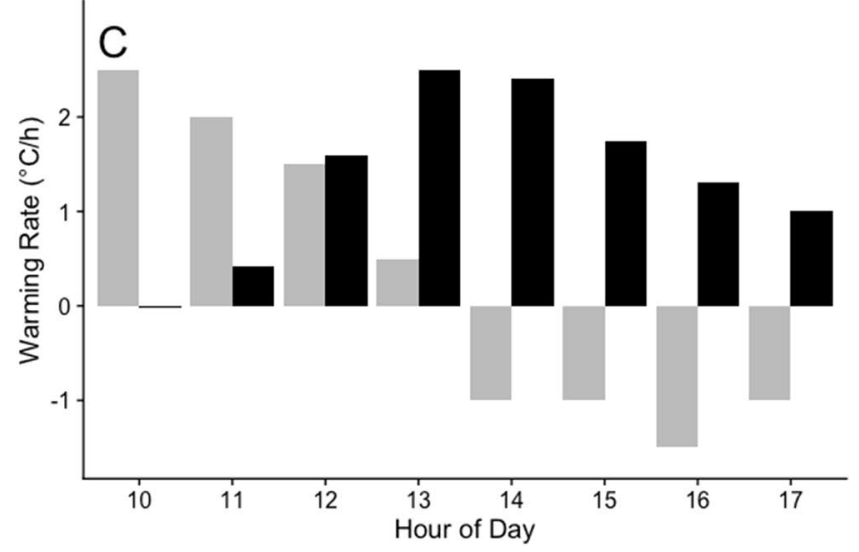

in $C$. C Warming rates of the animal (black bars) and the ambient temperature (grey bars). The animal started to rewarm at $\sim 1100 \mathrm{~h}$ and a body temperature of $\sim 35{ }^{\circ} \mathrm{C}$ was reached at around $1700 \mathrm{~h}$, i.e. the start of the scotophase. Hourly values are calculated as the average between the previous hour and depicted hour

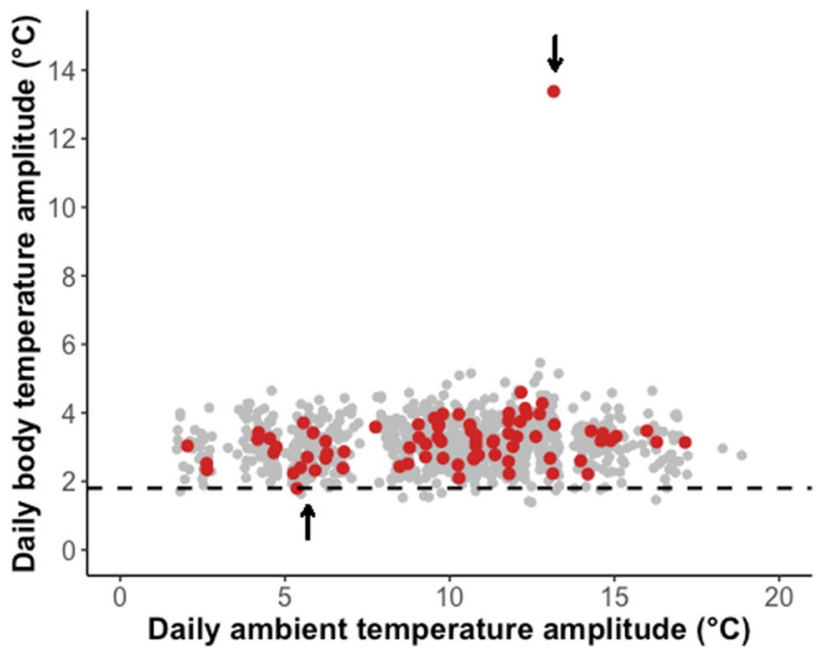

Fig. 3 Daily body temperature amplitude versus daily ambient temperature amplitude. Grey dots represent all 14 bush rats, red dots represent the individual showing the hypothermic bout. The dotted line marks a body temperature amplitude of $1.8{ }^{\circ} \mathrm{C}$ for comparison purposes. The arrows mark day of the hypothermic bout (daily amplitude $\left.>12{ }^{\circ} \mathrm{C}\right)$ and the day following the bout $\left(1.8^{\circ} \mathrm{C}\right)$ 
The individual maintained a stable $\mathrm{T}_{\mathrm{b}}$ on the day after the hypothermic bout with a daily amplitude of only $1.8^{\circ} \mathrm{C}$ (Fig. 3). Body temperature did not drop below $34.8^{\circ} \mathrm{C}$ on the other 76 days for which we recorded $\mathrm{T}_{\mathrm{b}}$ in the field for this individual. The animal was re-captured in good body condition (body mass gain of $+12 \mathrm{~g}$ since last March) at the end of June.

\section{Discussion}

Our data show that bush rats at our field site in Eastern Australia mostly kept their $\mathrm{T}_{\mathrm{b}}$ within a narrow range, with $\mathrm{a}$ higher $\mathrm{T}_{\mathrm{b}}$ during the nocturnal activity phase and a lower rest-phase $T_{b}$. Minimum $T_{b}$ of bush rats was lower on colder days and the amplitude between resting $T_{b}$ and active $T_{b}$ was largest during days with lower nightly minimum temperature. These data are largely in line with a previous fieldbased study of this species over a relatively short period of $<3$ weeks per season that found a winter decrease in mean $\mathrm{T}_{\mathrm{b}}$ and an increase in daily amplitude from $3.0^{\circ} \mathrm{C}$ in summer to $3.6{ }^{\circ} \mathrm{C}$ winter (Glanville and Seebacher 2010 ). $\mathrm{T}_{\mathrm{b}}$ levels varied slightly between both study populations and mean daily $\mathrm{T}_{\mathrm{b}}$ was $0.6^{\circ} \mathrm{C}$ to $0.8^{\circ} \mathrm{C}$ higher in our study than in the previous study, potentially due to local habitat adaptations. However, in contrast to the strict homeothermic $T_{b}$ regulation that the previous study has found (Glanville and Seebacher 2010), our data revealed a single hypothermic bout in one subadult individual in late autumn. This observation is the greatest daily reduction of $\mathrm{T}_{\mathrm{b}}$ recorded under field conditions in the genus Rattus and provides evidence for either a survivable bout of profound hypothermia or a controlled bout of torpor in these endemic Australian bush rats.

\section{Does the heterothermic bout represent a torpor bout?}

The observed decrease in $\mathrm{T}_{\mathrm{b}}$ to a minimum of $23.8{ }^{\circ} \mathrm{C}$ was $>12{ }^{\circ} \mathrm{C}$ greater than the normal diurnal variation observed in this population and poses the question of whether we have observed a bout of torpor-as defined by a temporary, reversible and controlled reduction of metabolic rate and, at $\mathrm{T}_{\mathrm{a}}$ less than $\mathrm{T}_{\mathrm{b}}$, a corresponding reduction in $T_{b}$ from normothermic values - or a bout of survivable hypothermia, which, in contrast to a torpor bout, involves high levels of metabolic heat production that nevertheless are insufficient to counter rates of heat loss, leading to an involuntary drop in $\mathrm{T}_{\mathrm{b}}$ (Geiser et al. 2014).

Timing of entry and rewarming from low $\mathrm{T}_{\mathrm{b}}$ was approximately corresponding with the early rest phase and thus similar to what has been reported for other daily heterotherms (Körtner and Geiser 2000). However, the early increase in $\mathrm{T}_{\mathrm{b}}$ before sunset, i.e. during the normal resting time and the later maintenance of a resting level $\mathrm{T}_{\mathrm{b}}$ during the active phase before the rather slow entry into the hypothermic bout are unusual for an otherwise nocturnal species. This almost certainly indicates that the individual did not exhibit activity and possibly did not forage for food during the night, and eventually was either not able to metabolically defend a high $T_{b}$ and entered hypothermia or voluntarily dropped $T_{b}$ to save energy during torpor.

Cooling and rewarming rates differ between regulated torpor and unregulated hypothermia: entry into hypothermia is slow at first, because of the high rate of metabolic heat production, and only becomes more rapid at lower $\mathrm{T}_{\mathrm{b}}$, matching the exponential negative effect of temperature on enzyme activity (Geiser et al. 2014). Warming from hypothermia begins passively with rising $\mathrm{T}_{\mathrm{a}}$, and hence usually slowly, and rewarming rate then increases with increasing $\mathrm{T}_{\mathrm{b}}$ as metabolic activity is increased (Geiser et al. 2014). Based on this criterion, cooling in the bush rat resembles entry into hypothermia, because the rate increased only after the body had started to cool. Nevertheless, maximum cooling rate was comparable to cooling rates recorded during torpor entry in the much smaller ash-gray mice, $P$. albocinereus, the only native Australian rodent species for which torpor has been confirmed via $\mathrm{T}_{\mathrm{b}}$ and metabolic rate data (Barker et al. 2012). Maximum cooling rate in ashgrey mice was $2.7^{\circ} \mathrm{C} \mathrm{h}^{-1}$, which is less than the maximum of $3.9{ }^{\circ} \mathrm{C} \mathrm{h}^{-1}$ recorded for the individual bush rat, even though the bush rat was more than twice the body mass of $P$. albocinerus (15-40 g; Barker et al. 2012). However, cooling rates are difficult to compare between the studies, because it is also dependent on the $\mathrm{T}_{\mathrm{a}}-\mathrm{T}_{\mathrm{b}}$ differential, which was less for $P$. albocinereus at a $\mathrm{T}_{\mathrm{a}}$ of $20{ }^{\circ} \mathrm{C}$ compared to that likely experienced by the bush rat.

The minimum $\mathrm{T}_{\mathrm{b}}$ of the bush rat during torpor was maintained at $\sim 24{ }^{\circ} \mathrm{C}$ for about $1.5 \mathrm{~h}$, which was $\sim 9{ }^{\circ} \mathrm{C}$ above external $\mathrm{T}_{\mathrm{a}}$ at this time. This could suggest that $\mathrm{T}_{\mathrm{b}}$ was maintained at a temporarily lowered set-point level such as found during regulated torpor (Heller and Colliver 1974), although it has to be considered that the microclimate surrounding the animal inside its nest might be buffered from the daily minimum $\mathrm{T}_{\mathrm{a}}$ causing a lower $\mathrm{T}_{\mathrm{a}}-\mathrm{T}_{\mathrm{b}}$ differential. Further, the phase during which $\mathrm{T}_{\mathrm{b}}$ was maintained at minimum level (i.e. the maintenance phase), might appear relatively short, but short maintenance phases during daily torpor are routinely observed in daily heterotherms, such as yellow footed antechinus, Antechninus flavipes, (Stawski et al. 2017; Reher et al. 2018) or the African lesser bushbaby, Galago moholi (Nowack et al. 2013b), and in some hibernating species, such as the Malagasy bat, Macronycteris commersoni (Reher et al. 2018).

The maximum rewarming rate of the bush rat was at $0.05{ }^{\circ} \mathrm{C} \min ^{-1}$ far less than expected for a similar-sized heterothermic species actively rewarming from torpor 
$\left(0.3{ }^{\circ} \mathrm{C} \mathrm{min}^{-1}\right.$ for a $72 \mathrm{~g}$ animal) (Geiser and Baudinette 1990) and correspondingly, the duration of rewarming of $6 \mathrm{~h}$ was longer than would be expected. However, unlike rewarming from hypothermia (Geiser et al. 2014), the maximum rewarming rate of the bush rat was faster at the beginning and slowed down later during the rewarming process. Slower rates of rewarming than those expected on the basis of body mass have been reported for some species that evidently underwent regulated torpor, such as in the primate G. moholi (Nowack et al. 2013b), the native Australian rodent P.albocinereus (Barker et al. 2012), and the monotreme echidna Tachyglossus aculeatus (Nicol et al. 2009). Indeed, maximum rewarming rates in bush rats were about twice as fast as those recorded for $P$. albocinereus $\left(2.75^{\circ} \mathrm{C} \mathrm{h}^{-1}\right.$, or $0.05^{\circ} \mathrm{C} \mathrm{min}^{-1}$ for the bush rat vs. $1.5^{\circ} \mathrm{C} \mathrm{h}^{-1}$ or $0.025^{\circ} \mathrm{C} \mathrm{min}^{-1}$ for P. albocinereus) (Barker et al. 2012), even though the bush rat is larger than the ash-gray mouse and should thus rewarm slower.

The animal could also have passively rewarmed with $\mathrm{T}_{\mathrm{a}}$, which increased in time with the initial period of rewarming of $T_{b}$. If the animal has been in a buffered resting site, the increase in $\mathrm{T}_{\mathrm{a}}$ might also have been delayed by a few hours. However, external $\mathrm{T}_{\mathrm{a}}$ was $\sim 9{ }^{\circ} \mathrm{C}$ lower than the animal's $\mathrm{T}_{\mathrm{b}}$ and the increase in $\mathrm{T}_{\mathrm{a}}$ was slower than the maximum rewarming rate of the animal. Hence, passive rewarming of $\mathrm{T}_{\mathrm{b}}$ by rising $\mathrm{T}_{\mathrm{a}}$ alone could not have been entirely responsible for warming of the hypothermic animal. However, it is possible that an increasing $\mathrm{T}_{\mathrm{a}}$ could have made active arousal easier by reducing the $T_{b}-T_{a}$ differential, especially during the earlier phase of rewarming. We think it highly unlikely the animal was exposed to direct solar radiation, because bush rats normally use underground burrows or ground nests under dense grass trees (Collins 1973; Frazer and Petit 2007). Basking in the sun should also have led to faster rewarming rates than those recorded. For example, dunnarts (Sminthopsis spp.) basking in sunlight can have a maximum passive arousal rates of up to $0.7{ }^{\circ} \mathrm{C} \mathrm{min}-1$ (Warnecke et al. 2008). Furthermore, two-step rewarming processes as observed in species that make use of passive rewarming normally start with an initial slow passive part and are followed by a faster active proportion after a certain $\mathrm{T}_{\mathrm{b}}$ was reached (e.g. Schmid 2000). Rewarming in the bush rat followed the opposite pattern.

The question whether the recorded drop in $\mathrm{T}_{\mathrm{b}}$ represents a controlled torpor bout or an unregulated bout of hypothermia unfortunately cannot be answered unequivocally based on the available data. Some aspects, such as the timing of entry and arousal and the successful rewarming suggest torpor, whereas others, such as the cooling process and the unusual low rewarming rate suggest it might instead have been a survivable bout of uncontrolled hypothermia.

\section{Implications of the hypothermic bout}

Regardless of whether the bush rat was in a state of uncontrolled hypothermia or a controlled state of torpor, our field observation do show that bush rats are able to survive a drop in $\mathrm{T}_{\mathrm{b}}$ to below $30^{\circ} \mathrm{C}$ for $\sim 5.5 \mathrm{~h}$, and are able to rewarm, albeit slowly, from a $\mathrm{T}_{\mathrm{b}}$ of $\sim 24^{\circ} \mathrm{C}$ with little if any reliance on external heat sources and without any apparent physiological damage. Small mammals have to cope with a high energy expenditure due to their small body size and high mass-specific rates of heat loss and they cannot survive for long without food intake while maintaining normothermic thermoregulation, especially when heat loss is increased at low $\mathrm{T}_{\mathrm{a}}$ (Howard 1951). Allowing $\mathrm{T}_{\mathrm{b}}$ to decrease can thus be beneficial and allow the animal to save energy, so long as the animal is able to rewarm again. Even lowering $\mathrm{T}_{\mathrm{b}}$ by $1.2^{\circ} \mathrm{C}$ leads to an energy saving of $6 \%$ of resting metabolic rate in a $126 \mathrm{~g}$ marsupial mammal (i.e. sugar glider; Christian and Geiser 2007). The use of deep regulated torpor can even reduce energy expenditure to as little as to $1 \%$ of energy expenditure during normothermic conditions (data for a $18 \mathrm{~g}$ hibernating marsupial pygmy possum at $\mathrm{Ta} \geq 5^{\circ} \mathrm{C}$; Geiser 1987), which can markedly increase an individual's survival chances without access to food. Thus, the reduction in $T_{b}$ observed in the bush rat would have reduced energy consumption, and such rare torpor bouts can be important for surviving exceptional circumstances during which foraging activity is impaired, such as unpredictable weather events (Nowack et al. 2017). However, the particular day was comparatively warm, with medium cloud cover (i.e. solar radiation) and no rainfall and thus the hypothermic bout observed for the bush rat cannot be explained by climatic conditions.

Unregulated hypothermia on the other hand can be lethal. When metabolic rate is not sufficient to maintain a stable elevated $\mathrm{T}_{\mathrm{b}}, \mathrm{T}_{\mathrm{b}}$ cools, and the high metabolic rate required for rewarming becomes impossible. Interestingly, even heterothermic species that can enter regulated torpor, such as the small marsupial antechinus (Antechinus stuartii), can become hypothermic when food deprived, i.e. they enter an unregulated state of hypothermia from which they cannot actively rewarm (Geiser 1988).

Laboratory studies report that at least some homeothermic rodents, i.e. species that are not known to undergo torpor, are able to survive periods of low $\mathrm{T}_{\mathrm{b}}$ if they are subsequently warmed by external heat sources. Popovic (1960) found that adult laboratory rats were able to recover from hypothermia with a $\mathrm{T}_{\mathrm{b}}$ as low as $15^{\circ} \mathrm{C}$, but only when hypothermia did not last more than $5.5 \mathrm{~h}$ (similar to our observation for the bush rat). When hypothermia lasted longer, rats were able to survive in a lethargic state at low $\mathrm{T}_{\mathrm{b}}$ but did not survive being warmed up to normothermic values, which seemed to have been related to changes in blood pressure (Popovic 1960). Furthermore, animals exposed to severe 
hypothermia typically develop cardiac arrythmia and/or fibrillation (e.g. Biörck and Johansson 1955). The native Australian sandy mouse, Pseudomys hermannsburgensis, can survive extended hypothermia for up to $32.5 \mathrm{~h}$ with a minimum $\mathrm{T}_{\mathrm{b}}$ of $17.3^{\circ} \mathrm{C}$ at a $\mathrm{T}_{\mathrm{a}}$ of $15^{\circ} \mathrm{C}$, when rewarmed passively (Tomlinson et al. 2007). In contrast, humans seem to be unable to survive deep hypothermia and generally maintain $T_{b}$ in very strict boundaries (reviewed in Shi et al. 2021). Juvenile animals are usually better in surviving episodes of low $\mathrm{T}_{\mathrm{b}}$. Hypothermic rat pups (Rattus norvegicus) can survive about $6 \mathrm{~h}$ of $\mathrm{T}_{\mathrm{b}}$ below $30^{\circ} \mathrm{C}$ under laboratory conditions, but need to be passively rewarmed (Geiser et al. 2014).

\section{How does this observation broaden our understanding of endotherm physiology?}

So far, we know of at least four species that are physiologically able to undergo regulated torpor but seem to not use torpor on a regular basis. These include the sandy inland mouse, bushbabies, sugar glider (Petaurus breviceps; Christian and Geiser (2007)) and feathertail glider (Acrobates pygmaeus; Jones and Geiser (1992)) and these observations of rare torpor use seem thus to be restricted to non-Holarctic species (Nowack et al. 2020). Unpublished evidence also suggests that the native Australian swamp rat (Rattus lutreolus) can survive a decrease in $\mathrm{T}_{\mathrm{b}}$ to $28{ }^{\circ} \mathrm{C}$ and seems able to rewarm spontaneously (C. Stawski, personal communication). Interestingly, at least two of the four species mentioned above also have low rewarming rates. As detailed above, rewarming rates for the bush rat are higher than those recorded for the sandy inland mouse, a species for which additional metabolic rate data have confirmed torpor use (Barker et al. 2012). Furthermore, the low rewarming rates from torpor observed in the African lesser bushbabies, Galago moholi, has led to the suggestion that bushbabies use torpor as a last resort strategy when energy reserves are low (Nowack et al. 2010, 2013b, a).

The finding of several mammal species that rarely use torpor with relatively low rewarming rates suggests these species can tolerate cold $T_{b}$ but are not adapted to rewarm by massively increasing metabolic rate at low $\mathrm{T}_{\mathrm{b}}$ like species that more regularly use torpor. While controversially discussed in the past (e.g. Geiser 2008), it is now assumed that ancestral mammals were largely heterothermic, i.e. had a high degree of thermoregulatory flexibility and survived periods of temporarily reduced $\mathrm{T}_{\mathrm{b}}$ (Lovegrove 2012; Ruf and Geiser 2015), and that heterothermy may have played an important role in the evolution of endothermy (Wacker et al. 2017; Geiser et al. 2017). Torpor and hibernation are widespread across mammalian orders, yet not all recent mammal lineages are able to undergo torpor or to survive longer periods of hypothermia (Ruf and Geiser 2015), which means that the ability to express heterothermy must have been lost multiple times in the course of mammalian evolution, while other linages apparently evolved the more regulated form of torpor use. Thus, observations of rare torpor events in species that otherwise appear to be strictly homeothermic could be heterothermic rudiments, i.e. an intermediate form of torpor that involves survivable hypothermia with limited capacity for rewarming. Those data are only coming to light with long-term datasets of animals that capture their rare and extreme responses. Our data also emphasise the value of additionally recording metabolic rate (e.g. via heart rate; Currie et al. 2014) along with $T_{b}$, which would allow to make assumptions about energy expenditure during the cooling period and rewarming process and can thus be helpful to differentiate between unregulated hypothermia and torpor use.

Acknowledgements We like to thank Arne Müller, Alex Romano, Danielle Croall and Callum Fleming for their help during field work and Danielle L. Levesque for sharing R scripts for body temperature analysis and plotting.

Author contributions All authors designed and planned the study. JN conducted the fieldwork, analysed the data and wrote the first version of the manuscript. CT edited the manuscript and provided resources and logistical support.

Funding The project was financially supported via an Endeavour Fellowship and a grant from the Western Sydney University to JN.

Data availability Data are available on request.

\section{Declarations}

Conflict of interest The authors declare no competing interests/conflicts of interest.

Ethical approval The study was approved by the institutional animal care and ethics committee (ACEC number: A11402) and a scientific licence from the NSW National Parks and Wildlife Service (Scientific Licence number: SL101679).

Open Access This article is licensed under a Creative Commons Attribution 4.0 International License, which permits use, sharing, adaptation, distribution and reproduction in any medium or format, as long as you give appropriate credit to the original author(s) and the source, provide a link to the Creative Commons licence, and indicate if changes were made. The images or other third party material in this article are included in the article's Creative Commons licence, unless indicated otherwise in a credit line to the material. If material is not included in the article's Creative Commons licence and your intended use is not permitted by statutory regulation or exceeds the permitted use, you will need to obtain permission directly from the copyright holder. To view a copy of this licence, visit http://creativecommons.org/licenses/by/4.0/. 


\section{References}

Agostinelli C, Lund U (2017) R package 'circular': Circular Statistics (version 0.4-93). https://r-forge.r-project.org/projects/circular/

Barak O, Geiser F, Kronfeld-Schor N (2018) Flood-induced multiday torpor in golden spiny mice (Acomys russatus). Aust J Zool 66(6):401-405. https://doi.org/10.1071/ZO19061

Barker JM, Cooper CE, Withers PC, Cruz-Neto AP (2012) Thermoregulation by an Australian murine rodent, the ash-grey mouse (Pseudomys albocinereus). Comp Biochem Physiol A Mol Integr Physiol 163(3-4):336-342. https://doi.org/10.1016/j.cbpa.2012. 07.011

Bennett A, Ruben J (1979) Endothermy and activity in vertebrates. Science 206(4419):649-654. https://doi.org/10.1126/science.493968

Biörck G, Johansson B (1955) Comparative studies on temperature effects upon the electrocardiogram in some vertebrates. Acta Physiol Scand 34(2-3):257-272. https://doi.org/10.1111/j.17481716.1955.tb01245.x

Bivand R, Lewin-Koh N (2019) Maptools: tools for handling spatial objects. R package version 0.9-9.

Chmura HE, Glass TW, Williams CT (2018) Biologging physiological and ecological responses to climatic variation: new tools for the climate change era. Front Ecol Evol 6:92. https://doi.org/10.3389/ fevo.2018.00092

Christian N, Geiser F (2007) To use or not to use torpor? Activity and body temperature as predictors. Naturwissenschaften 94(6):483487. https://doi.org/10.1007/s00114-007-0215-5

Collins BG (1973) The ecological significance of thermoregulatory responses to heat stress shown by two populations of an Australian murid, Rattus fuscipes. Comp Biochem Physiol A Physiol 44(4):1129-1140. https://doi.org/10.1016/0300-9629(73)90251-X

Currie SE, Körtner G, Geiser F (2014) Heart rate as a predictor of metabolic rate in heterothermic bats. J Exp Biol 217(9):1519-1524. https://doi.org/10.1242/jeb.098970

Frazer DS, Petit S (2007) Use of Xanthorrhoea semiplana (grasstrees) for refuge by Rattus fuscipes (Southern bush rat). Wildl Res 34(5):379-386. https://doi.org/10.1071/WR06123

Geiser F (1987) Hibernation and daily torpor in two pygmy-possums (Cercartetus spp., Marsupialia). Physiol Zool 60(1):93-102

Geiser F (1988) Daily torpor and thermoregulation in antechinus (Marsupialia): influence of body mass, season, development, reproduction, and sex. Oecologia 77(3):395-399. https://doi. org/10.1007/bf00378050

Geiser F (2004) Metabolic rate and body temperature reduction during hibernation and daily torpor. Annu Rev Physiol 66:239-274. https://doi.org/10.1146/annurev.physiol.66.032102.115105

Geiser F (2008) Ontogeny and phylogeny of endothermy and torpor in mammals and birds. Comp Biochem Physiol A Mol Integr Physiol 150(2):176-180. https://doi.org/10.1016/j.cbpa.2007. 02.041

Geiser F, Baudinette RV (1990) The relationship between body mass and rate of rewarming from hibernation and daily torpor in mammals. J Exp Biol 151:349-359

Geiser F, Körtner G (2010) Hibernation and daily torpor in Australian mammals. Aust Zool 35(2):204-215

Geiser F, Holloway JC, Körtner G, Maddocks TA, Turbill C, Brigham RM (2000) Do patterns of torpor differ between free-ranging and captive mammals and birds? In: Heldmaier G, Klingenspor M (eds) Life in the Cold. Springer Berlin Heidelberg, Berlin, Heidelberg, pp 95-102

Geiser F, Holloway J, Körtner G (2007) Thermal biology, torpor and behaviour in sugar gliders: a laboratory-field comparison. J Comp Physiol B 177(5):495-501. https://doi.org/10.1007/ s00360-007-0147-6
Geiser F, Currie SE, O'Shea KA, Hiebert SM (2014) Torpor and hypothermia: reversed hysteresis of metabolic rate and body temperature. Am J Physiol Regul Integr Comp Physiol 307(11):R1324R1329. https://doi.org/10.1152/ajpregu.00214.2014

Geiser F, Stawski C, Wacker CB, Nowack J (2017) Phoenix from the ashes: fire, torpor, and the evolution of mammalian endothermy. Front Physiol 8:842. https://doi.org/10.3389/fphys.2017.00842

Glanville EJ, Seebacher F (2010) Plasticity in body temperature and metabolic capacity sustains winter activity in a small endotherm (Rattus fuscipes). Comp Biochem Physiol A Mol Integr Physiol 155(3):383-391. https://doi.org/10.1016/j.cbpa.2009.12.008

Glanville EJ, Murray SA, Seebacher F (2012) Thermal adaptation in endotherms: climate and phylogeny interact to determine population-level responses in a wild rat. Funct Ecol 26(2):390-398. https://doi.org/10.1111/j.1365-2435.2011.01933.x

Heller HC, Colliver GW (1974) CNS regulation of body temperature during hibernation. Am J Physiol 227(3):583-589. https://doi.org/ 10.1152/ajplegacy.1974.227.3.576

Howard WE (1951) Relation between low temperature and available food to survival of small rodents. J Mammal 32(3):300-312. https://doi.org/10.2307/1375662

Jones CJ, Geiser F (1992) Prolonged and daily torpor in the feathertail glider, Acrobates pygmaeus (Marsupialia: Acrobatidae). J Zool 227(1):101-108. https://doi.org/10.1111/j.1469-7998.1992.tb043 47. $\mathrm{x}$

Körtner G, Geiser F (2000) The temporal organization of daily torpor and hibernation: circadian and circannual rhythms. Chronobiol Int 17(2):103-128. https://doi.org/10.1081/cbi-100101036

Levesque DL, Tuen AA, Lovegrove BG (2018) Staying hot to fight the heat-high body temperatures accompany a diurnal endothermic lifestyle in the tropics. J Comp Physiol B 188(4):707-716. https:// doi.org/10.1007/s00360-018-1160-7

Lovegrove BG (2012) The evolution of endothermy in Cenozoic mammals: a plesiomorphic-apomorphic continuum. Biol Rev 87(1):128-162. https://doi.org/10.1111/j.1469-185X.2011. 00188.x

Morton SR, Lee AK (1978) Thermoregulation and metabolism in Planigale maculata (Marsupialia: Dasyuridae). J Therm Biol 3(3):117-120. https://doi.org/10.1016/0306-4565(78)90003-7

Nagy KA (2005) Field metabolic rate and body size. J Exp Biol 208(9):1621-1625. https://doi.org/10.1242/jeb.01553

Nicol SC, Andersen NA, Arnold W, Ruf T (2009) Rewarming rates of two large hibernators: comparison of a monotreme and a eutherian. J Therm Biol 34(3):155-159. https://doi.org/10.1016/j.jther bio.2009.01.003

Nowack J, Mzilikazi N, Dausmann KH (2010) Torpor on demand: heterothermy in the non-lemur primate Galago moholi. PLoS ONE 5(5):e10797. https://doi.org/10.1371/journal.pone.0010797

Nowack J, Dausmann KH, Mzilikazi N (2013a) Nonshivering thermogenesis in the African lesser bushbaby, Galago moholi. J Exp Biol 216(20):3811-3817. https://doi.org/10.1242/jeb.089433

Nowack J, Mzilikazi N, Dausmann KH (2013b) Torpor as an emergency solution in Galago moholi: heterothermy is triggered by different constraints. J Comp Physiol B 183:547-556. https://doi. org/10.1007/s00360-012-0725-0

Nowack J, Rojas AD, Körtner G, Geiser F (2015) Snoozing through the storm: torpor use during a natural disaster. Sci Rep 5:11243. https://doi.org/10.1038/srep11243

Nowack J, Stawski C, Geiser F (2017) More functions of torpor and their roles in a changing world. J Comp Physiol B 187(5):889897. https://doi.org/10.1007/s00360-017-1100-y

Nowack J, Levesque DL, Reher S, Dausmann KH (2020) Variable climates lead to varying phenotypes: "weird" mammalian torpor and lessons from non-holarctic species. Front Ecol Evol 8:60. https:// doi.org/10.3389/fevo.2020.00060 
Pinheiro J, Bates D, DebRoy S, Sarkar D, R Core Team (2021) nlme: linear and nonlinear mixed effects models. $\mathrm{R}$ package version 3.1153. https://CRAN.R-project.org/package $=$ nlme

Popovic V (1960) Physiological characteristics of rats and ground squirrels during prolonged lethargic hypothermia. Am J Physiol 199:467-471. https://doi.org/10.1152/ajplegacy.1960.199.3.467

R Development Core Team (2019) R: a language and environment for statistical computing. R Foundation for Statistical Computing, Vienna

Reher S, Ehlers J, Rabarison H, Dausmann KH (2018) Short and hyperthermic torpor responses in the Malagasy bat Macronycteris commersoni reveal a broader hypometabolic scope in heterotherms. J Comp Physiol B 188(6):1015-1027. https://doi.org/10.1007/ s00360-018-1171-4

Renninger M, Sprau L, Geiser F (2020) White mouse pups can use torpor for energy conservation. J Comp Physiol B 190(2):253-259. https://doi.org/10.1007/s00360-020-01263-8

Romano AB, Hunt A, Welbergen JA, Turbill C (2019) Nocturnal torpor by superb fairy-wrens: a key mechanism for reducing winter daily energy expenditure. Biol Lett 15(6):20190211. https://doi.org/10. 1098/rsbl.2019.0211

Ruf T, Geiser F (2015) Daily torpor and hibernation in birds and mammals. Biol Rev 90:891-926. https://doi.org/10.1111/brv.12137

Ruf T, Streicher U, Stalder GL, Nadler T, Walzer C (2015) Hibernation in the pygmy slow loris (Nycticebus pygmaeus): multiday torpor in primates is not restricted to Madagascar. Sci Rep 5:17392. https://doi.org/10.1038/srep17392

Schmid J (2000) Daily torpor in the gray mouse lemur (Microcebus murinus) in Madagascar: energetic consequences and biological significance. Oecologica 123:175-183

Schubert KA, Boerema AS, Vaanholt LM, de Boer SF, Strijkstra AM, Daan S (2010) Daily torpor in mice: high foraging costs trigger energy-saving hypothermia. Biol Lett 6(1):132-135. https://doi. org/10.1098/rsbl.2009.0569

Seebacher F, Glanville EJ (2010) Low levels of physical activity increase metabolic responsiveness to cold in a rat (Rattus fuscipes). PLoS ONE 5(9):e13022-e13022. https://doi.org/10.1371/ journal.pone.0013022

Shi Z, Qin M, Huang L, Xu T, Chen Y, Hu Q, Peng S, Peng Z, Qu L-N, Chen S-G, Tuo Q-H, Liao D-F, Wang X-P, Wu R-R, Yuan T-F,
Li Y-H, Liu X-M (2021) Human torpor: translating insights from nature into manned deep space expedition. Biol Rev 96(2):642672. https://doi.org/10.1111/brv.12671

Stawski C, Nowack J, Körtner G, Geiser F (2017) A new cue for torpor induction: charcoal, ash and smoke. J Exp Biol 220:220-226. https://doi.org/10.1242/jeb.146548

Tomlinson S, Withers PC, Cooper C (2007) Hypothermia versus torpor in response to cold stress in the native Australian mouse Pseudomys hermannsburgensis and the introduced house mouse Mus musculus. Comp Biochem Physiol A Mol Integr Physiol 148(3):645-650. https://doi.org/10.1016/j.cbpa.2007.08.013

Turbill C, Stojanovski L (2018) Torpor reduces predation risk by compensating for the energetic cost of antipredator foraging behaviours. Proc Royal Soc B Biol Sci 285(1893):20182370. https:// doi.org/10.1098/rspb.2018.2370

Turbill C, Bieber C, Ruf T (2011) Hibernation is associated with increased survival and the evolution of slow life histories among mammals. Proc Royal Soc B Biol Sci 278(1723):3355-3363. https://doi.org/10.1098/rspb.2011.0190

Turbill C, McAllan BM, Prior S (2019) Thermal energetics and behaviour of a small, insectivorous marsupial in response to the interacting risks of starvation and predation. Oecologia 191(4):803-815. https://doi.org/10.1007/s00442-019-04542-6

Wacker CB, McAllan BM, Körtner G, Geiser F (2017) The role of basking in the development of endothermy and torpor in a marsupial. J Comp Physiol B. https://doi.org/10.1007/s00360-017-1060-2

Warnecke L, Turner J, Geiser F (2008) Torpor and basking in a small arid zone marsupial. Naturwissenschaften 95(1):73-78. https:// doi.org/10.1007/s00114-007-0293-4

Zhao ZD, Yang WZ, Gao C, Fu X, Zhang W, Zhou Q, Chen W, Ni X, Lin JK, Yang J, Xu XH, Shen WL (2017) A hypothalamic circuit that controls body temperature. Proc Natl Acad Sci USA 114(8):2042-2047. https://doi.org/10.1073/pnas.1616255114

Publisher's Note Springer Nature remains neutral with regard to jurisdictional claims in published maps and institutional affiliations. 